\title{
SIMULATION OF THE ENERGY GRADIENT OF THE LATERAL LINE WITH TYPE MF2 MICRO-SPRINKLERS
}

\author{
SIMULAÇÃO DO GRADIENTE DE ENERGIA DA LINHA LATERAL COM \\ MICROASPERSORES TIPO MF2
}

\section{Gabriel Siqueira Tavares Fernandes $1 \oplus$, Kenny Ruben Montalvo Morales ${ }^{2} \oplus$, Victor Gurgel Pessoa $^{1} \oplus$, Vynicius Barbosa de Oliveira ${ }^{\circledR}{ }^{\oplus}$, Edivania de Araujo Lima ${ }^{4} \oplus$, Tomás Guilherme Pereira da Silva ${ }^{5}$}

\footnotetext{
${ }^{1}$ Mestre em Engenharia agrícola, Universidade Federal Rural de Pernambuco, Recife, PE, Brasil.

${ }^{2}$ Doutorando em Engenharia agrícola, Universidade Federal Rural de Pernambuco, Recife, PE, Brasil.

${ }^{3}$ Mestrando em Ciências ambientais, Universidade Federal do Pará, Belém, PA, Brasil.

${ }^{4}$ Prof. Doutor em Zootecnia, Universidade Federal de Alagoas, Arapiraca, AL, Brasil.

${ }^{5}$ Profa. Doutora em Meteorologia, Universidade Federal do Piauí, Universidade Federal do Piauí, Bom Jesus, Brasil
}

\begin{abstract}
The objective of this study was to evaluate the hydraulic pressure gradient along the lateral line of microsprinklers, using the $\mathrm{Wu}$ and Gitlin model. Mathematical simulations were developed in an electronic spreadsheet in Microsoft Excel software (2016). Where the adapted equation of the Blasius model was determined, the energy gradient along the lateral line, the length of the lateral line (L), the number of emitters $(\mathrm{N})$, the length of the adjusted lateral line (Lajst), the number of fitted emitters (Najst), the flow velocity $\left(\mathrm{m}^{2} \mathrm{~s}-\right.$ 1) loss and the charge along the entire length of the lateral line $\mathrm{L} h \mathrm{hf}^{\prime}(\mathrm{L})$. The pressure and flow variation of the micro-sprinklers has a direct influence on the uniformity of water application along the lateral line. In addition, the suggested formula is representative for estimating the Darcy-Weisbach $f$ factor, within the parameters and conditions of simulations used, as well as the black nozzle of the Amanco MF2 type microsprinkler had greater variation in the energy gradient and flow, along the lateral line, in relation to the orange nozzle.
\end{abstract}

Keywords: hydraulics, localized irrigation, mathematical model

RESUMO: Objetivou-se avaliar o gradiente de pressão hidráulico ao longo da linha lateral de microaspersores, por meio do modelo de Wu e Gitlin. As simulações matemáticas foram desenvolvidas em planilha eletrônica no software Microsoft Excel (2016). Onde determinou-se a equação adaptada do modelo de Blasius, o gradiente de energia ao longo da linha lateral, comprimento da linha lateral (L), o número de emissores (N), o comprimento da linha lateral ajustada (Lajst), o número de emissores ajustados (Najst), a velocidade do escoamento $\left(\mathrm{m}^{2} \mathrm{~s}-1\right)$ e a perda de carga ao longo de todo o comprimento da linha lateraL hf '(L). A variação da pressão e da vazão dos microaspersores tem influência direta na uniformidade de aplicação de água no decurso da linha lateral. Além disso, a fórmula sugerida é representativa para estimativa do fator $\mathrm{f}$ de Darcy-Weisbach, dentro dos parâmetros e das condições de simulações utilizadas, bem como, o bocal preto do microaspersor tipo MF2 da Amanco possuiu maior variação no gradiente de energia e na vazão, no decorrer da linha lateral, em relação ao bocal laranja.

Palavras-chave: hidráulica, irrigação localizada, modelo matemático. 


\section{INTRODUCTION}

The application of sustainable development and proper management of water resources is valid for irrigation, considering that this system requires a large amount of water to supply agricultural crops (PRADO; COLOMBO, 2013). It is noteworthy that the scarcity of water availability and quality, lack of adequate instrumentation, energy consumption, among other factors, are relevant to determine the irrigation system to be used (FRIZZONE et al., 2012; DE LA ROSA et al. ., 2015),, so that the water needs of the crop are met, with efficient and economic use of these resources.

In this context, micro-irrigation or localized irrigation stands out, which includes micro-sprinkler and drip irrigation. In this type of irrigation there is a minimum loss of water in favor of the high efficiency of application of the system (SOUZA et al., 2020). Microsprinkler is characterized by the application of water to the soil with low intensity and high frequency, through microsprinklers, causing low water losses by evaporation and conduction (SARAIVA et al., 2014).

There is a list of micro-sprinklers available on the market, which vary in flow and reach, due to the diameter of the nozzles and types of inserts, respectively. Thus, in a lateral line, the water distribution is directly dependent on the diameter of the nozzles and jet inclination, in addition to operating conditions such as service pressure, installation height and stability of the emitter support rod (ANDRADE; ZANINI; SOARES, 2015).

In addition, there are factors of an uncontrolled nature generated by the pressure drop in the pipe, causing an energy gradient in the lateral line and, consequently, heterogeneity in the water distribution. One of the ways to obtain the head loss is through the Darcy-Weisbach equation, which depends on a friction factor (f) that varies according to the flow conditions (BOMBARDELLI; GARCÍA, 2003) and, among several forms of estimating f explicitly, the Blasius model stands out.
The Blasius equation, used for smooth turbulent flow flow regimes, depends only on the Reynolds number and two dimensionless constants and has simplicity (SOUSA; DANTAS NETO, 2014). However, the model has limitations, so its accuracy is valid only for the Reynolds Number (NR) range from 4,000 to 100,000 (VON BERNUTH, 1990; SOUSA; DANTAS NETO 2014). On the other hand, the model proposed by Offor and Alabi (2016) has been gaining prominence, due to its accuracy and its range of NR from 4000 to 100,000,000 (PIMENTA et al., 2018).

In this sense, the objective was to evaluate the hydraulic pressure gradient along the lateral line of microsprinklers, using the $\mathrm{Wu}$ and Gitlin model.

\section{MATERIAL AND METHODS}

Darcy-Weisbach's f factor was obtained through the equation proposed by Offor and Alabi (2016), which is represented as the most accurate alternative methodology to the implicit $f$ of Colebrook-White, namely:

$\frac{1}{\sqrt{f}}=-2 \log \left\{\frac{\varepsilon}{3,71 D}-\frac{1,975}{R e}\left[\ln \left(\left(\frac{\varepsilon}{3,93 D}\right)^{1,092}+\left(\frac{7,627}{R e+395,9}\right)\right)\right]\right\}$

Where: $\mathrm{f}$ is the Darcy-Weisbach factor (dimensionless); $\operatorname{Re}$ is the Reynolds (dimensionless) number; $\mathrm{D}$ is the inner diameter of the pipe $(\mathrm{m}) \mathrm{e}$; $\varepsilon$ is the absolute pipe roughness $(\mathrm{m})$.

The Reynolds Number (Re) can be obtained with the following equation:

$$
R e=\frac{V * D}{v}
$$

where: $\mathrm{V}$ is the flow velocity in the pipeline $(\mathrm{m} \mathrm{s}-1) ; v$ is the kinematic viscosity of water (m2 s-1); Di is the inner diameter of the pipe (m).

The Blasius equation, whose application is the Reynolds Number from 4000 to 100,000 (Von Bernuth 1990), is 
expressed as (AZEVEDO NETTO et al., 1998; PORTO, 2006):

$$
f=0,316 * R e^{-0,25}
$$

Where: $\mathrm{f}$ is the Darcy-Weisbach factor (dimensionless); $\operatorname{Re}$ is the Reynolds (dimensionless) number.The simulations were based on the methodology proposed by Sousa and Dantas Neto (2014), being carried out in Microsoft Excel software (2016), with pipe diameters of $13,16,20,26,32$ and $40 \mathrm{~mm}$; flow velocity $0.5 ; 1.0 ; 1.5 ; 2.0 ; 2.5$ and $3.0 \mathrm{~m}$ s-1.

The kinematic viscosity of water equal to0,00000101 m2 s-1. By plotting the data of the factor $\mathrm{f}$ resulting from Equation 1 in relation to the Reynolds Number, via regression analysis in a potential model, the equation adapted from the Blasius model was obtained.

Subsequently, the equation found was validated from the values obtained by the method of Offor and Alabi (2016), which were considered the real values in the comparisons.

When it comes to determining the energy gradient along the lateral line, the microsprinklers were chosen taking into account their commercialization, applicability, durability, low cost of installation and maintenance. Thus, the Amanco ${ }^{\circledR}$ model MF2 micro-sprinklers, with a black and orange nozzle of 0.90 and $1.80 \mathrm{~mm}$, respectively. In the simulation, an average flow of 48,2 L h-1 and a working pressure of 25 m.c.a. The hydraulic characteristics of each emitter can be seen in Table 1.

Table 1: Pressure energy $(\mathrm{H})$ and flow (q) of Amanco® type MF2 micro-sprinklers, black and orange nozzle.

\begin{tabular}{cccc}
\hline \multicolumn{2}{c}{ Black nozzle } & \multicolumn{3}{c}{ Orange nozzle } \\
\hline $\mathrm{H}(\mathrm{m} . \mathrm{c} . \mathrm{a})$ & $\mathrm{q}(\mathrm{L} / \mathrm{h})$ & $\mathrm{H}$ (m.c.a) & $\mathrm{q}(\mathrm{L} / \mathrm{h})$ \\
\hline 12 & 34 & 12 & 100,4 \\
15 & 38 & 15 & 100,2 \\
20 & 43,3 & 20 & 128,8 \\
25 & 48,2 & 25 & 144 \\
30 & 52,6 & 30 & 157,4 \\
35 & 56,7 & 35 & 170,2
\end{tabular}

D: Diameter; H: Service pressure; q: Microsprinkler flow

For the calculation procedure, adjustment coefficients derived from the relationship between pressure energy and flow are needed, these parameters are related to the influence of pressure variation on flow and can be obtained by formulating Equation 4 (KELLER ; KARMELI, 1974). Thus, to obtain these, a linear regression analysis was performed between the data provided in Table 1.

$$
q=k * H^{x}
$$

Where: $\mathrm{q}$ is the flow of the sender in (l.h-1); $\mathrm{k}$ is the discharge coefficient, which is a characteristic value of each emitter (dimensionless); $\mathrm{H}$ is the pressure energy at the emitter input (m.c.a) and; $x$ is the emitter 
discharge exponent that expresses the emitters' sensitivity to pressure variations.

The sizing was performed in Microsoft Excel software (2016), where, from the data obtained, the length of the lateral line (L), the number of emitters $(\mathrm{N})$, the length of the adjusted lateral line (Lajst), the number of fitted emitters (Najst), the flow velocity $\left(\mathrm{m}^{2} \mathrm{~s}-\right.$ 1 ), and the pressure drop along the entire length of the lateral lineL $\mathrm{hf}$ ' (L).

Thus, the simulation of the pressure profile along the lateral line was done using the sizing equation given by $\mathrm{Wu}$ and Gitlin (1975) which is expressed as:

$$
H i=H_{0}-\left(1-\left(1-\frac{l}{L}\right)^{m+1}\right) * h f,
$$

Where: Hi is the pressure energy at the emitter $i$ (mca), 1 is the position of the microsprinkler along the lateral line $(\mathrm{m}), \mathrm{L}$ is the total length of the lateral line $(\mathrm{m}), \mathrm{m}$ is the flow coefficient in the equation in use and hf' is total pressure drop on the line (m.c.a.).

$$
\begin{aligned}
& L=\left[1,051 * 10^{14} * D i^{4,75} *\left(\frac{H}{x}\right) *\left(\frac{S e}{q}\right)^{1,75}\right]^{\frac{1}{2,75}} \\
& h f_{(L)}^{\prime}=k\left(\frac{q}{s e}\right)^{m} * L^{m+1} * \frac{1}{m+1}
\end{aligned}
$$

Where: $\mathrm{L}$ is the length of the lateral line (m); Di is the inner diameter of the pipe ( $\mathrm{mm})$; $\mathrm{H}$ is the service pressure (m.c.a) ; $\mathrm{x}$ is the emitter discharge exponent that expresses the emitters' sensitivity to pressure variations; If it is the spacing between emitters $(\mathrm{m})$; what is the average discharge (l.h-1) and; $m$ is the coefficient of flow in the equation in use.

It is worth noting that the input data used in the dimensioning process are shown in Table 2 and that the chosen pipe diameter was $16 \mathrm{~mm}$.

Table 2: Initial data used for the dimensioning of the lateral irrigation line located with Amanco® type MF2 micro-sprinklers, with black and orange nozzles.

\begin{tabular}{lc}
\hline \multicolumn{2}{c}{ Micro sprinkler input data } \\
\hline Service pressure (P.S) (m.c.a) & 25 \\
Spacing $(\mathrm{S})(\mathrm{m})$ & 1,2 \\
Temperature $(\mathrm{T})\left({ }^{\circ} \mathrm{C}\right)$ & 20 \\
Kinematic Viscosity of Water $\left(\mathrm{m}^{2} / \mathrm{s}\right)$ & $1.10^{-6}$ \\
M & 1,75 \\
Slope $(\mathrm{m})$ & 0 \\
\hline
\end{tabular}

\section{RESULTS AND DISCUSSION}

In each diameter, the data of $\mathrm{f}$ were related to the $\mathrm{Re}$, where a high coefficient of determination was obtained. $\left(\mathrm{R}^{2}\right)$ for all situations (Figure 1), observing an inversely proportional relationship between the analyzed variables. 
Simulation of the energy gradient of the lateral line with type MF2 micro-sprinklers
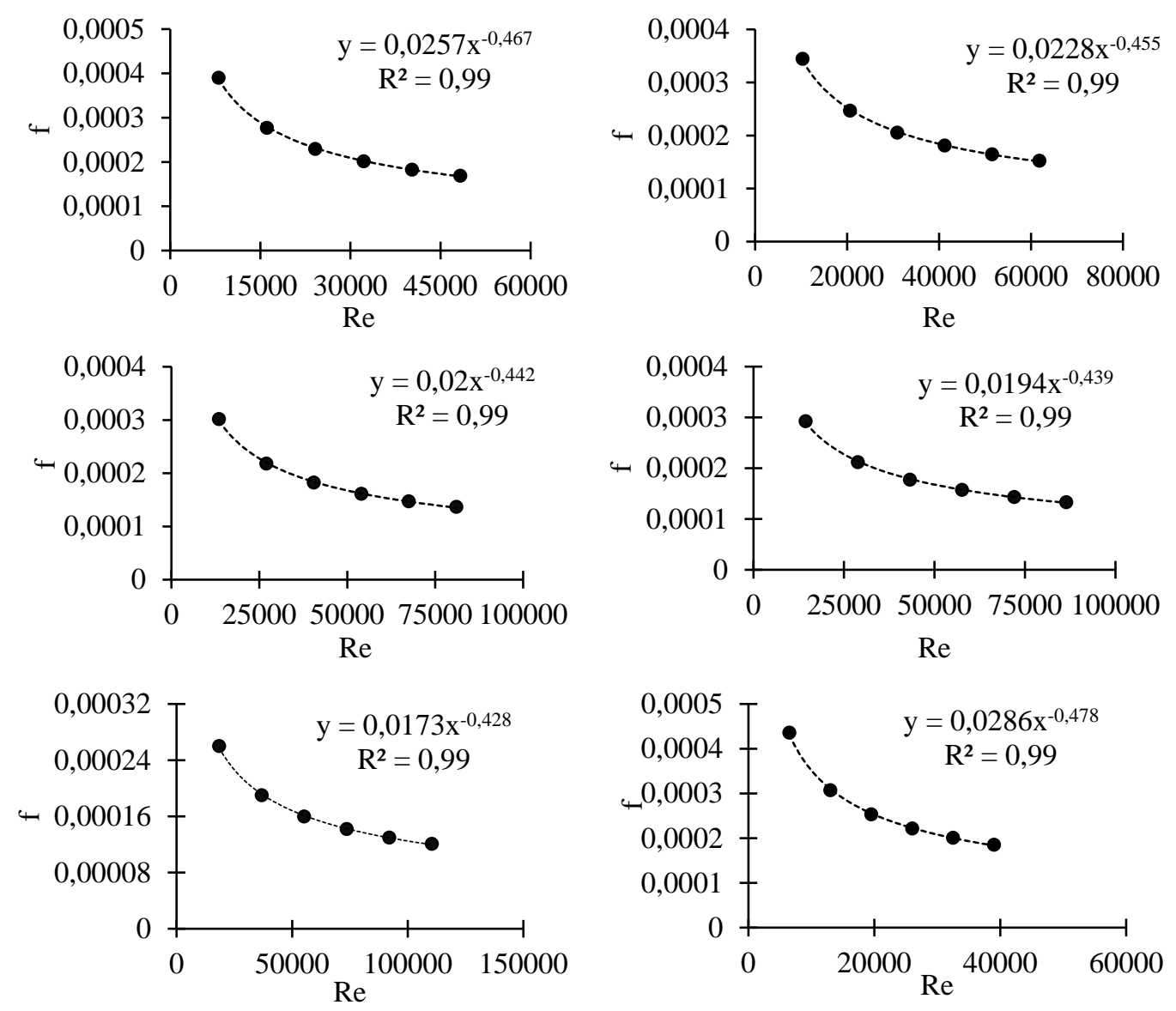

Figure 1. Potential model regression analysis for Darcy-Weisbach $\mathrm{f}$ factor (f) and Reynolds Number (Re) for pipe diameters 13 (a), 16 (b), 20 (c), 26 (d), 32 (e) and $40 \mathrm{~mm}$ (f).

With the obtainment of the coefficients $\mathrm{C}$ in for each diameter (Figure 1), according to the model of the Blasius equation, these were related to the inner diameter of the pipe (Di),

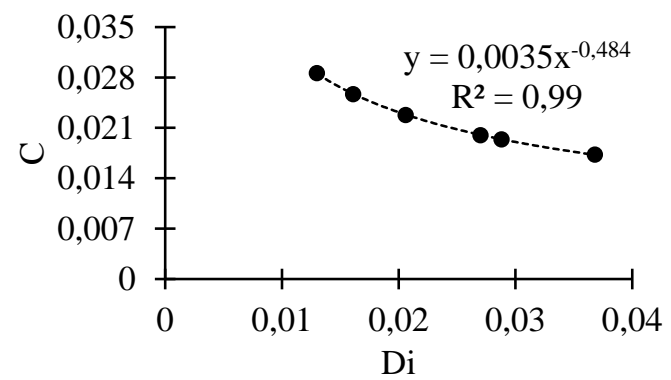

in order to have an equation that enables the calculation of constants in favor of the $\mathrm{Di}$ (mm) (Figure 2).

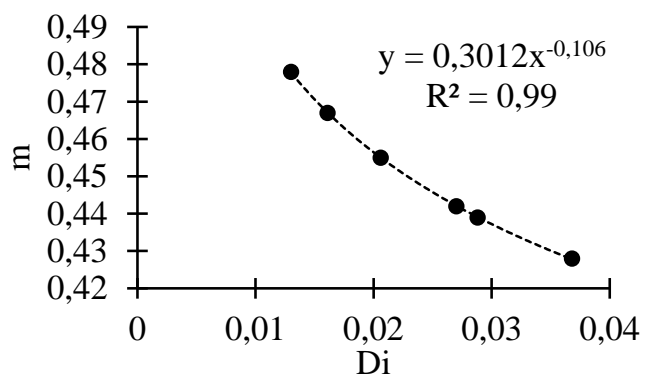

Figure 2. Regression analysis in a potential model between the pipe inner diameter and the constants of the Blasius equation, $\mathrm{C}$ (a) and $\mathrm{m}(\mathrm{b})$.

This way, it is possible to calculate the factor $\mathrm{f}$, with the simplicity and ease of the Blasius model and with the precision of the Offor and Alabi (2016) model, from the following equation:

$f=\left(0,0035 * D i^{-0,484}\right) * R e^{-\left(0,3012 * D i^{-0,106}\right)}$
In which: $\mathrm{f}$ is the Darcy-Weisbach factor (dimensionless); $\mathrm{Re}$ is the Reynolds number (dimensionless) e; Di is the inner diameter of the pipe $(\mathrm{m})$. It is noteworthy that the equation found makes the calculation of $f$ even more efficient because the Blasius constants are variable in favor 
of the inner diameter, which is not taken into account in most models available. Furthermore, through the high coefficient of determination $\left(\mathrm{R}^{2}=\right.$
0,99), note that Equation 3 is representative for estimating the variable $f$ by the equation of Offor and Alabi (2016) (Figure 3).

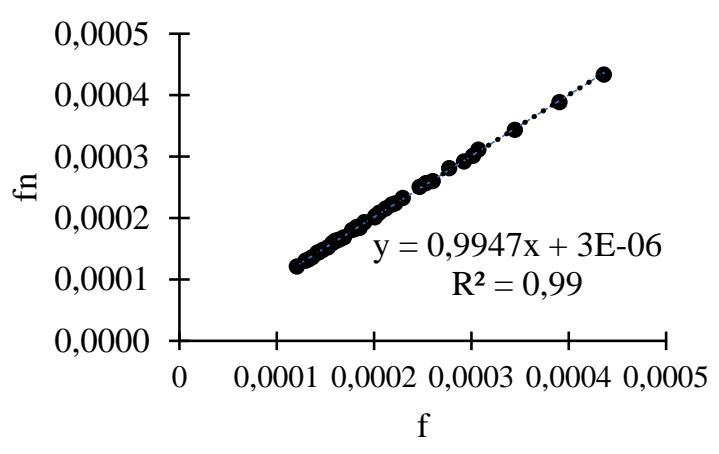

Figure 3. Validation between the Darcy-Weisbach $\mathrm{f}$ factor variables obtained by the Offor and Alabi equation (f) and the suggested adapted equation (fn).

Thus, the equation suggested by the present work can be used, within the parameters and conditions of simulations presented here, to estimate the DarcyWeisbach factor $\mathrm{f}$, with the application range varying from $4000<\operatorname{Re}<100,000,000$, from accurately and efficiently. Similar results, applied through the same methodology, were found by Sousa and Dantas Neto (2014), with the adaptation of the von Kármán model to that of Blasius.

With regard to the lateral line energy gradient, the related hydraulic characteristics as well as the adapted equations for the emitters are displayed in Figure 4.
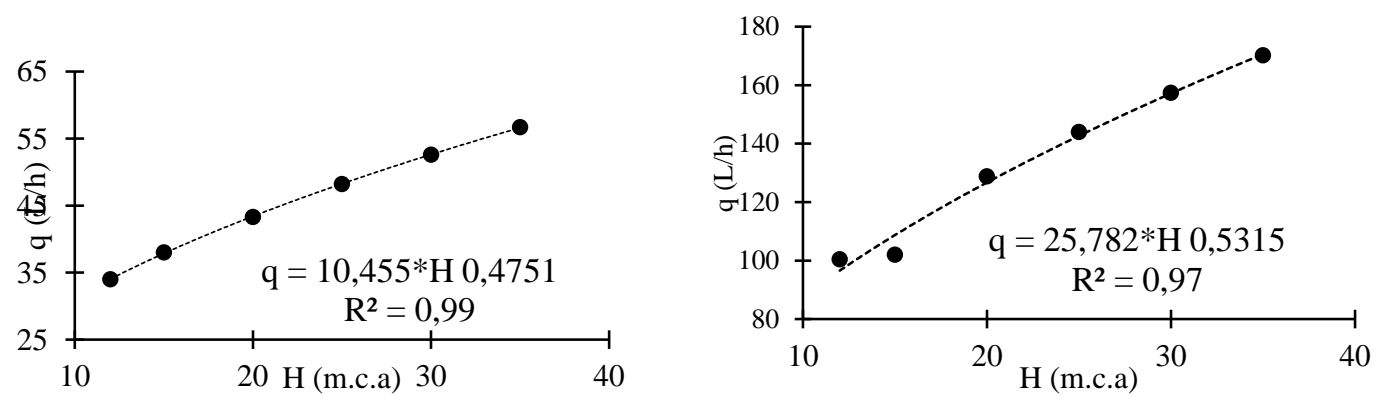

Figure 4. Regression analysis between pressure energy $(\mathrm{H})$ and flow (q) of the black (a) and orange (b) emitters.

As can be seen in Figure 4, the $\mathrm{x}$ coefficients were 0.4751 for the black nozzle and 0.5315 for the orange nozzle, with 0 being the perfect exponent for the flow equation (PIZARRO, 1990), the black nozzle, as it has a smaller coefficient, is more efficient and has a smaller influence of pressure variations on the water flow in each emitter. For some pipe diameters, the length of the lateral line (L), the number of emitters $(\mathrm{N})$, the length of the adjusted lateral line (Lajst), the number of fitted emitters (Najst) and the flow velocity were obtained. 
Table 3. Inside Diameter (Di), Line Side Length (L), Number of Emitters (N), Adjusted Line Length Side (Lajst), Number of Emitters (Najst) and Flow Velocity (v) for different pipe nominal diameters.

\begin{tabular}{ccccccc}
\hline \multicolumn{7}{c}{ Nozzle, black color } \\
\hline Dn (mm) & Di (m) & L (m) & N & N ajst & L ajst & v $\left(\mathrm{m} \mathrm{s}^{-1}\right)$ \\
\hline 13 & 0,0130 & 25,76 & 21,47 & 21 & 25,2 & 2,12 \\
16 & 0,0161 & 37,28 & 31,07 & 31 & 37,2 & 2,04 \\
20 & 0,0260 & 85,31 & 71,09 & 71 & 85,2 & 1,79 \\
26 & 0,0270 & 91,05 & 75,88 & 76 & 91,2 & 1,78 \\
32 & 0,0288 & 101,79 & 84,83 & 85 & 102 & 1,75 \\
40 & 0,0368 & 155,45 & 129,54 & 130 & 156 & 1,64 \\
\hline
\end{tabular}

Nozzle, orange color

\begin{tabular}{ccccccc}
\hline Dn (mm) & Di (m) & L (m) & N & N Ajust & L ajist & v $\left(\mathrm{m} \mathrm{s}^{-1}\right)$ \\
\hline 13 & 0,0130 & 12,33 & 10,27 & 10 & 12 & 3,01 \\
16 & 0,0161 & 17,83 & 14,86 & 15 & 18 & 2,95 \\
20 & 0,0260 & 40,81 & 34,01 & 34 & 40,8 & 2,56 \\
26 & 0,0270 & 43,56 & 36,30 & 36 & 43,2 & 2,52 \\
32 & 0,0288 & 48,70 & 40,58 & 40 & 48 & 2,46 \\
40 & 0,0368 & 74,37 & 61,97 & 62 & 74,4 & 2,33 \\
\hline
\end{tabular}

The use of the $16 \mathrm{~mm}$ diameter in the dimensioning configured a lateral line of 37.2 $\mathrm{m}$ and 31 emitters for the black nozzle and 18 $\mathrm{m}$ and 15 emitters for the orange nozzle. The difference between the nozzles, for the variables analyzed, is in favor of the inner diameter of the nozzle. Thus, the black nozzle, having a smaller diameter $(0.9 \mathrm{~mm})$ compared to the orange one $(1.8 \mathrm{~mm})$, has a lower water emission flow at the same service pressure and, consequently, the line has capacity to support a greater number of these issuers. In this context, the pressure energy in each emitter was obtained, in the respective nozzles, along the lateral line, characterizing the energy gradient (Figure 5). 

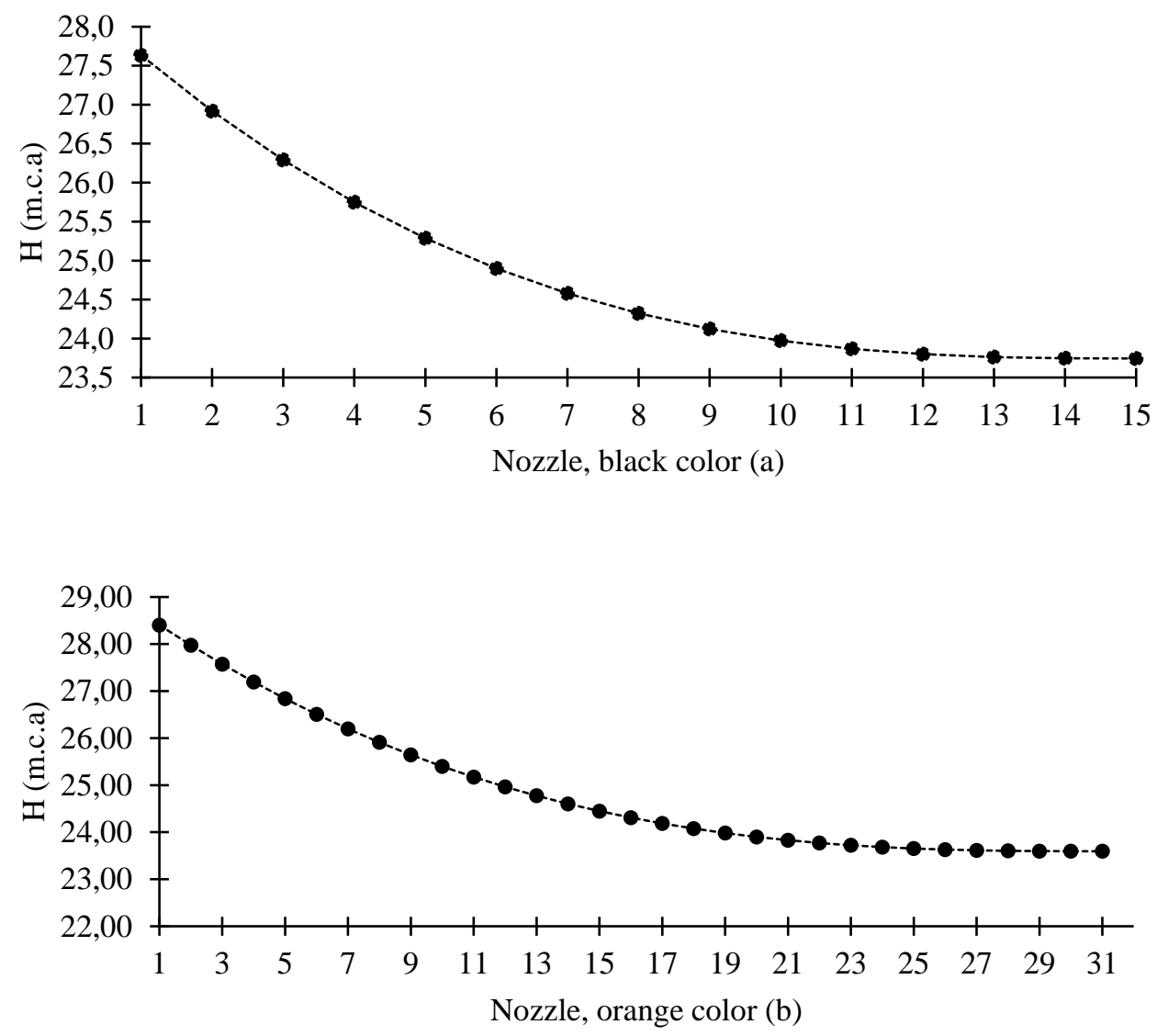

Figure 5. Energy gradient (m.c.a) along sideline of Amanco® type MF2 emitters, black (a) and orange nozzle (b).

As it can be seen in Figure 5, the variation in energy along the line for both nozzles is remarkable. For the black nozzle (Figure 5a) there is a variation of $17 \%$ between the first and last emitter. On the other hand, the orange nozzle has a variation of $14 \%$ between the same issuers.
With regard to head loss, the black nozzle had greater loss (4.8 m.c.a), compared to the orange (3.9 m.c.a.), precisely because it has a larger lateral line and a larger number of emitters. Flow variation along the lateral line was also noticeable between the emitters of each nozzle (Figure 6). 

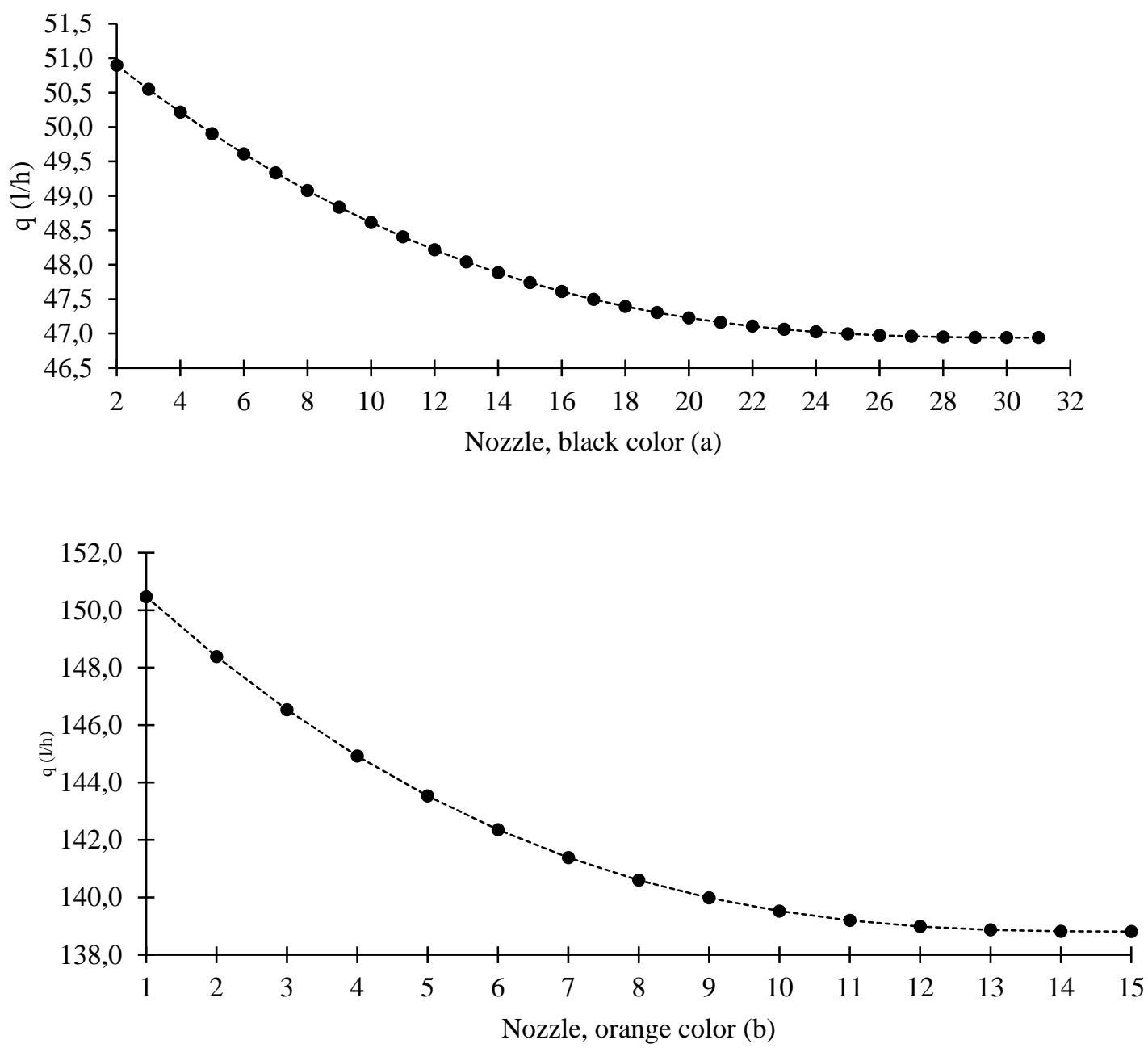

Figure 6. Flow variation $\left(\mathrm{L} \mathrm{h}^{-1}\right)$ along the sideline of Amanco® type MF2 transmitters, with black (a) and orange (b) nozzles.

Thus, in localized irrigation systems, the uniform distribution of the application of blades along the lateral line is directly related to the variation in pressure and flow of emitters, thus, changes in pressure caused by pressure loss cause flow variation ( SILVA; SILVA, 2005).

As can be seen in Figures 5 and 6, the mouthpiece that showed greater uniformity was the orange one, thus ensuring a better distribution of water along the lateral line, when compared to the black mouthpiece.

\section{CONCLUSIONS}

The suggested formula is representative for estimating the Darcy-Weisbach f factor, within the parameters and conditions of the simulations used, with a wide range of variation of the Reynolds Number.

The black nozzle of the Amanco MF2 microsprinkler had greater variation in the energy gradient and flow along the lateral line compared to the orange nozzle, which suggests that it has a better distribution of water along the lateral line.

\section{REFERENCES}

ANDRADE, S. M.; ZANINI, J. S.; SOARES, C. A.; Desempenho hidráulico de microaspersor autocompensante, novo e usado. Semina: Ciências Agrárias, v.36, nº, p. 3517 - 3528, 2015. 
AZEVEDO NETTO, J. M. Manual de hidraúlica. 8. ed. São Paulo: Edgard Blücher, 1998. 670 p.

BOMBARDELLI, F. A.; GARCIA, M. H. Hydraulic design of large-diameter pipes. Journal of Hydraulic Engineering, v.129, nº11, p 839 - 846, 2003.

DE LA ROSA, J. M.; DOMINGO, R.; GÓMEZ-MONTIEL, J.; PÉREZ-PASTOR, A. Implementing déficit irrigation scheduling through plant water stress indicators in early nectarine trees. Agricultural Water Management, v.152, p. 207-216, 2015.

FRIZZONE, J. A.; FREITAS, P. S. L.; REZENDE, R.; FARIA, M. A. Microirrigação: Gotejamento e Microaspersão. 1. ed. Maringí: Editora Eudem, 2012. 356 p.

KELLER, J.; KARMELI D. Trickle irrigation design parameters. Transactions of the ASAE, v.17, $\mathrm{n}^{\circ} 4, \quad$ p. 0678 0684, 1974.

MACEDO, A. B. M.; GOMES FILHO, R. R.; LIMA, S. C. R. V.; VALNIR JÚNIOR, M.; CAVALCANTE JÚNIOR, J. A. H.; ARAÚJO, H. F. Desempenho Hidráulico de um sistema de irrigação por microaspersão utilizando dois tipos de emissores. Revista Brasileira de Agricultura Irrigada, v.4, $\mathrm{n}^{\circ} 2$, p. $82-86,2010$.

OFFOR, U. H.; ALABI, S. B.; An accurate and computationally efficient friction factor model. Advances in Chemical Engineering and Science, v.6, nº3, p. 237 - 245, 2016.

PIMENTA, B. D.; ROBAINA, A. D.; PEITER, M. X.; MEZZOMO, W.; KIRCHNER, J.H.; BEM, L. H. Performance of explicit approximations of the coefficient of head loss for pressurized conduits. Revista Brasileira de Engenharia Agrícola e Ambiental, v.22, n5, p. 301 - 307, 2018.
PIZARRO, F. Riegos localizados de alta frecuencia. 2. ed. Madrid: Ediciones Mundiprensa, 1990. 461p.

PORTO, R. D. M. Hidráulica básica. 4. ed. São Carlos: Eesc-USP, 2006. 540p.

PRADO, G.; COLOMBO, A. Interpolação de perfis radiais de distribuição de água de aspersores. Revista Brasileira de Engenharia Agrícola e Ambiental, v.17, nº 4, p. 355 - 361, 2013.

SARAIVA, K. R.; REBOUÇAS, R. M.; SOUZA, F. S. Desempenho de um sistema de irrigação por microaspersão na cultura do coqueiro. Agropecuária Técnica, v. $35, \mathrm{n}^{\circ} 1, \mathrm{p}$. $62-68,2014$.

SILVA, C. A.; SILVA, C. J. da. Avaliação de uniformidade em sistemas de irrigação localizada. Revista Científica Eletrônica de Agronomia, ano IV, n. 8, 2005.

SOUSA, J. S. C.; DANTAS NETO, J. Equação explícita para cálculo do fator de atrito de Darcy-Weisbach em projetos de irrigação pressurizada. Brazilian Journal of Irrigation and Drainage, v. $19, \mathrm{n}^{\circ} 1$, p. 137 148, 2014.

ALMEIDA SOUZA, E.; FERREIRA COELHO, E.; PEDREIRA SANTOS, F.; MAGALHÃES DE MELO, D.; SOUZA CAMPOS, M.; CASTRO COUTO, J. S. Distribuição da umidade e condutividade elétrica em Latossolo com cobertura morta em bananeira fertirrigada. Revista Brasileira de Agricultura Irrigada, v. 14, n. 4, 2020.

VON BERNUTH, R. D. Simple and accurate friction loss equation for plastic pipes. Journal of Irrigation and Drainage Engineering, v.116, p. 294 - 298, 1990.

WU, I. P.; GITLIN, H. M. Energy gradient line for drip irigation laterals. Journal of the Irrigation and Drainage Division, v.101, no 4, p. $323-326,1975$. 